\title{
Detection of Neisseria gonorrhoeae antigen by a solid-phase enzyme immunoassay
}

\author{
H A AARDOOM,* D DE HOOP,† C O A ISERIEF,† M F MICHEL, ${ }^{*}$ AND E STOLZ† \\ From the *Department of Clinical Microbiology and Antimicrobial Therapy, and the + Department of \\ Dermatovenereology, Erasmus University Rotterdam, Rotterdam, The Netherlands
}

SUMMARY The Gonozyme test (Abbott Laboratories) is a new enzyme immunoassay for detecting Neisseria gonorrhoeae antigens in specimens from the urethra in men and the endocervix in women. To evaluate the usefulness of the assay 249 patients were investigated. The results obtained with the immunoassay were compared with those of culture and microscopy of Gramstained smears. The sensitivity and specificity of the test were high in men with urethritis and acceptable in different groups of women. As the sensitivity of the Gonozyme test was much higher than that of microscopy for endocervical specimens it might be useful as a rapid screening test for the detection of gonorrhoea in women.

\section{Introduction}

The diagnosis of gonorrhoea is usually based on the detection of Gram-negative diplococci in Gramstained smears and the isolation of Neisseria gonorrhoeae from urethral or endocervical material. A gonococcal infection might, however, also be detected by the presence of antigen in material from infected patients. For this purpose the Gonozyme test (Abbott Laboratories) has been developed; it can be read in three hours and uses a solid-phase enzyme immunoassay for the detection of gonococcal antigen in material from the male urethra and the endocervical canal of women. Because of possible crossreactions with Neisseria lactamica and Neisseria meningitidis the testing of rectal and pharyngeal material by immunoassay is not recommended.

In the present study appropriate specimens for Gram-staining, culture, and the Gonozyme test were collected from four well-defined groups of patients attending a sexually transmitted diseases (STD) clinic.

\section{Patients and methods}

\section{REAGENTS}

The Gonozyme diagnostic kit consists of the following reagents: beads pretreated to facilitate absorption of $N$ gonorrhoeae antigen; antibody to

Address for reprints: Professor Dr M F Michel, Department of Clinical Microbiology and Antimicrobial Therapy, Erasmus University Rotterdam, PO Box 1738, 3000 DR Rotterdam, The Netherlands

Accepted for publication 30 May 1982
$N$ gonorrhoeae obtained by injecting different gonococcal strains into rabbits'; antibody-enzyme conjugate, the antibody having been prepared by immunising goats with rabbit IgG and the enzyme used being horseradish peroxidase; a positive and negative control; and specimen storage solution and specimen dilution buffer. O-phenylenediamine $2 \mathrm{HCl}$ (OPD) was used as the substrate in the enzyme immunoassay.

\section{STUDY GROUPS}

Two hundred and forty-nine patients were investigated and divided into four groups: (A) 52 men with symptoms of urethritis; (B) 54 female contacts of patients suspected of having a gonococcal infection; (C) 41 patients ( 15 men and 26 women) who were reexamined after treatment for gonorrhoea; and (D) 102 prostitutes who regularly attended the STD clinic for the control of STDs.

\section{COLLECTION OF SPECIMENS}

Using a bacteriological loop material for Gramstaining was obtained from the male urethra and the endocervical canal of women. A second swab was used to collect specimens for gonococcal culture and for the immunoassay. As calcium alginate and the glue of wood may elicit false-positive reactions in the assay cottonwool-tipped plastic swabs were used in this study.

A chocolate agar plate and a Thayer-Martin plate were inoculated immediately after the collection of the specimen and, using a loop, the inoculum was spread over the plates. After incubation the density of the growth was graded from 1 to 4 . After 
inoculation of the plates the swab was immersed in $0.2 \mathrm{ml}$ of specimen storage solution in a $15-\mathrm{ml}$ conical centrifuge tube; the tube was stored at $4^{\circ} \mathrm{C}$. Before the assay was performed $1 \mathrm{ml}$ of specimen dilution buffer was added to the tube. After 2-5 minutes the swab was rotated vigorously for 15 seconds, expressed against the wall of the tube, and discarded. All assays were performed within 24-48 hours of specimen collection.

\section{PERFORMANCE OF ASSAY}

Wells of a tray were filled with $0.2 \mathrm{ml}$ of the specimen or appropriate control. A bead was then dispensed into each well and after incubation of the covered tray for 15 minutes at $37^{\circ} \mathrm{C}$ the beads were washed three times with distilled water. The next two steps consisted of the addition of $0.2 \mathrm{ml}$ of antibody to $N$ gonorrhoeae and $0.2 \mathrm{ml}$ of antibody-enzyme conjugate. Each of these steps was followed by incubation of the trays and washing of the beads as described. After the last washing all excess water was removed from the wells and each bead was transferred to a tube; $0.3 \mathrm{ml}$ of freshly prepared OPD solution was added to each tube and the tubes were left at room temperature for 10 minutes. The enzyme reaction was stopped by the addition of $1 \mathrm{ml}$ of $\mathrm{NHCl}$ to the tubes containing a bead and to the substrate blank. After mixing the tubes were read in a spectrophotometer at $492 \mathrm{~nm}$. Specimens giving values greater than $1 \cdot 1$ times the cutoff value were considered positive for $N$ gonorrhoeae. The cutoff value was defined as a reading of 0.15 plus the mean of at least two negative controls. Values within $10 \%$ of the cutoff value were considered to be doubtful results.

COMPARISON OF THE ASSAY SCORES

As false-negative results can occur the findings on microscopy or culture cannot be used as absolute criteria for the existence of a gonococcal infection. ${ }^{23}$
TABLE I Formula for comparing sensitivity and specificity of Gonozyme immunoassay with those of microscopy and culture

\begin{tabular}{lll}
\hline & \multicolumn{2}{l}{ Immunoassay results } \\
\cline { 2 - 3 } Culture/microscopy results & Positive & Negative \\
\hline \begin{tabular}{lll} 
Positive & $\mathrm{a}$ & $\mathrm{b}$ \\
Negative & $\mathrm{c}$ & $\mathrm{d}$ \\
\hline $\mathrm{a}+\mathrm{b}=\mathrm{x} ; \mathrm{c}+\mathrm{d}=\mathrm{y}: \mathrm{a}+\mathrm{c}=\mathrm{p} ; \mathrm{b}+\mathrm{d}=\mathrm{q} ;$ total number $\mathrm{x}+\mathrm{y}$ \\
$=\mathrm{p}+\mathrm{q}=\mathrm{z}$
\end{tabular}
\end{tabular}

For this reason the results obtained with cultures and immunoassays were compared. From these comparisons two sensitivities and two specificities could be deduced. The same indices could be estimated when the results of microscopy and immunoassays were compared. According to the formula in table I the sensitivities and specificities were defined as follows: when the results of microscopy and culture were compared with those of immunoassay sensitivity equalled $a / x$ and specificity $d / y$; when results of immunoassay were compared with those of culture or microscopy sensitivity was defined as $\mathbf{a} / \mathrm{p}$ and specificity as $\mathrm{d} / \mathrm{q}$. In groups with negative microscopy or culture results and positive assay results and in those with positive microscopy or culture results but negative assay results the results were discordant. The figures of the discordant results were used for the estimation of the degree of misclassification, this index being defined as $(b+c) / z$.

\section{Results}

COMPARISON OF IMMUNOASSAY AND CULTURE

The results of the immunoassays and cultures in each of the four groups of patients and in all patients are given in table II. The mutual sensitivities and

TABLE II Comparison of the sensitivities and specificities of the immunoassay and bacterial culture in four groups of patients

\begin{tabular}{|c|c|c|c|c|c|c|c|c|c|c|}
\hline & \multicolumn{8}{|c|}{ Patient groups } & & \\
\hline & \multicolumn{2}{|l|}{$\boldsymbol{A}$} & \multicolumn{2}{|l|}{$B$} & \multicolumn{2}{|l|}{ C } & \multicolumn{2}{|l|}{$D$} & \multicolumn{2}{|c|}{ All patients } \\
\hline & No & $\% *$ & No & $\%^{*}$ & No & $\% *$ & No & $\% *$ & No & $\%^{*}$ \\
\hline \multicolumn{11}{|l|}{ Assay $v s$ culture } \\
\hline $\begin{array}{l}\text { Sensitivity } \\
\text { Specificity }\end{array}$ & $\begin{array}{l}35 / 35 \\
17 / 17\end{array}$ & $\begin{array}{l}90-100 \\
81-100\end{array}$ & $\begin{array}{l}13 / 15 \\
35 / 39\end{array}$ & $\begin{array}{l}60-98 \\
76-97\end{array}$ & $\begin{array}{c}2 / 3 \\
36 / 38\end{array}$ & $82-99$ & $\begin{array}{l}11 / 12 \\
87 / 90\end{array}$ & $\begin{array}{l}62-100 \\
91-99\end{array}$ & $\begin{array}{c}61 / 65 \\
175 / 184\end{array}$ & $\begin{array}{l}85-98 \\
90-98\end{array}$ \\
\hline \multicolumn{11}{|l|}{ Culture vs assay } \\
\hline $\begin{array}{l}\text { Sensitivity } \\
\text { Specificity }\end{array}$ & $\begin{array}{l}35 / 35 \\
17 / 17\end{array}$ & $\begin{array}{l}90-100 \\
81-100\end{array}$ & $\begin{array}{l}13 / 17 \\
35 / 37\end{array}$ & $\begin{array}{l}50-93 \\
82-99\end{array}$ & $\begin{array}{c}2 / 4 \\
36 / 37\end{array}$ & $86-100$ & $\begin{array}{l}11 / 14 \\
87 / 88\end{array}$ & $\begin{array}{l}49-95 \\
94-100\end{array}$ & $\begin{array}{c}61 / 70 \\
175 / 179\end{array}$ & $\begin{array}{l}77-94 \\
94-99\end{array}$ \\
\hline Misclassification & $0 / 52$ & $0-7$ & $\begin{array}{r}30 / 54 \\
6 / 51\end{array}$ & $\begin{array}{r}02-9 y \\
4-23\end{array}$ & $3 / 41$ & $2-20$ & $4 / 102$ & $1-10$ & $13 / 249$ & $3-9$ \\
\hline
\end{tabular}

*95\% confidence intervals are given as probability percentages 
specificities and the degree of misclassification with both methods are shown.

Group $A$-In none of the 52 patients were the results discordant; the sensitivities and specificities were high. Group B-Of the 54 patients, the immunoassay results were negative in two patients in whom $N$ gonorrhoeae was isolated on culture and positive in four patients from whom the organism was not cultured. The $95 \%$ confidence limits of the sensitivities and specificities were dependent on the number of patients in the group (table II).

Group C-Of the 41 patients, the assay result was negative in one patient from whom $N$ gonorrhoeae was cultured and positive in two patients in whom the organism was not isolated; the specificities were high. Group D-Of the 102 women, the immunoassay was negative in one infected patient and positive in three patients in whom the culture results were negative.

Of the total 249 patients the assay results were negative in four patients from whom $N$ gonorrhoeae was isolated and positive in nine patients in whom the organism was not cultured. The $95 \%$ confidence limits of sensitivities and specificities for all patients were high.

\section{COMPARISON OF IMMUNOASSAY AND MICRO- SCOPY}

The results of the immunoassays and microscopy are given in table III. In six patients (two from group A, two from group B, and two from group D) Gramstained smears were not prepared and were not included in the following analysis.

Group $A$-Of 50 patients, the assay was positive in one in whom the microscopy result was negative.

Group $B$-Of 54 patients, typical organisms were seen on the smear of exudate from one patient in whom the assay result was negative. The results of the assay for 16 patients in whom Gram-negative diplococci were not seen were positive. When compared with the immunoassay the sensitivity of microscopy was low.
Group C-In three of 39 patients in whom Gramnegative diplococci were not seen the assay was positive. Specificities were high.

Group $D$-The assay results were positive in 13 of 100 women in whom Gram-negative diplococci were not seen on microscopy. Compared with the immunoassay the sensitivity of microscopy was low and the specificity was high.

Only one of the 243 patients had negative assay results but positive results on microscopy. In 33 patients the assay was positive although microscopy of a Gram-stained smear was negative. When compared with microscopy the sensitivity and specificity of the assay was high.

\section{DISCORDANT RESULTS WITH CULTURE AND IMMUNOASSAY}

Although the immunoassay results were negative $N$ gonorrhoeae was isolated from material from four patients. In eight women and in one man gonococci were not cultured but the immunoassay results were positive. Because some uncommon gonococcal strains might have remained undetected by the Gonozyme test the following experiment was devised. Serial 10-fold dilutions of dense suspensions of each of four isolates were made in trypticase soy broth. After a sample had been taken for counting a swab was immersed in each tube and used for semiquantitative cultures and immunoassay. The results are shown in table IV. The growth densities and the assay readings obtained with the clinical specimens are compared with those of the semiquantitative culture. The results from the clinical specimens corresponded fairly well with those obtained in the experiment; the sensitivity of the immunoassay (case Nos 1 and 16) was higher for some isolates than others (case Nos 2 and 15).

\section{GROWTH DENSITY OF CULTURES}

The mean growth density of gonococcal cultures in group A was $3 \cdot 5$, in group B $2 \cdot 1$, in group C $2 \cdot 4$, and in group D $2 \cdot 5$.

TABLE III Comparison of the sensitivities and specificities of the immunoassay and microscopy in four groups of patients

\begin{tabular}{|c|c|c|c|c|c|c|c|c|c|c|}
\hline & \multicolumn{8}{|c|}{ Patient groups } & & \\
\hline & \multicolumn{2}{|l|}{$A$} & \multicolumn{2}{|l|}{$B$} & \multicolumn{2}{|l|}{$C$} & \multicolumn{2}{|l|}{$D$} & \multicolumn{2}{|c|}{ All patients } \\
\hline & No & $\% *$ & No & $\%^{*}$ & No & $\%^{*}$ & No & $\% *$ & No & $\%^{*}$ \\
\hline \multicolumn{11}{|c|}{ Assay vs microscopy } \\
\hline Sensitivity & $33 / 33$ & $89-100$ & $1 / 2$ & & $1 / 1$ & & $1 / 1$ & & $36 / 37$ & $86-100$ \\
\hline Specificity & $16 / 17$ & $71-100$ & $35 / 52$ & $55-81$ & $35 / 38$ & $79-98$ & $86 / 99$ & $79-93$ & $173 / 206$ & 78-88 \\
\hline \multicolumn{11}{|c|}{ Microscopy vs assay } \\
\hline Sensitivity & $33 / 34$ & $85-100$ & $1 / 17$ & $0 \cdot 1-29$ & $1 / 4$ & & $1 / 14$ & $0 \cdot 2-34$ & $36 / 69$ & $40-64$ \\
\hline Specificity & $16 / 16$ & $79-100$ & $36 / 37$ & $86-100$ & $35 / 35$ & $90-100$ & $86 / 86$ & $96-100$ & $173 / 174$ & $96-100$ \\
\hline Misclassification & $1 / 50$ & $0 \cdot 1-11$ & $17 / 54$ & $19-45$ & $3 / 39$ & $2-21$ & $13 / 100$ & $7-21$ & $34 / 243$ & $10-20$ \\
\hline
\end{tabular}

* $95 \%$ confidence limits are given as probability percentages 
TABLE IV Comparison of the results of bacterial culture and immunoassay of four gonococcal isolates from infected patients or from serial dilutions in broth

\begin{tabular}{|c|c|c|c|c|c|}
\hline \multicolumn{3}{|c|}{ Clinical isolates } & \multicolumn{3}{|l|}{ Serial dilutions } \\
\hline Case No & Growth density & $\begin{array}{l}\text { Immunoassayt } \\
\text { reading }\end{array}$ & Growth density & $\begin{array}{l}\text { Immunoassayt } \\
\text { reading }\end{array}$ & $\begin{array}{l}\text { No of organisms } / \mathrm{ml} \\
\text { in broth }\end{array}$ \\
\hline $\begin{array}{r}2 \\
15 \\
1 \\
16\end{array}$ & $\begin{array}{l}3 \\
1-2 \\
1 \\
1-2\end{array}$ & $\begin{array}{l}0.056 \\
0.587 \\
0.105 \\
0.945\end{array}$ & $\begin{array}{r}4 \\
2 \\
1 \\
<1\end{array}$ & $\begin{array}{l}0.183 \\
0.196 \\
0.300 \\
0.475\end{array}$ & $\begin{array}{l}1.0 \times 105 \ddagger \\
2.7 \times 104 \ddagger \\
6.0 \times 103 \S \\
1.5 \times 102 \S\end{array}$ \\
\hline
\end{tabular}

† Reading $>0.17$ is positive and $<0.13$ is negative

₹Minimum number of gonococci per $\mathrm{ml}$ TSB giving a positive result in the immunoassay

$\S$ Inoculum giving a visible density on agar of $\leqslant 1$ and a positive reaction in the immunoassay

\section{Discussion}

In relation to bacterial culture the sensitivity and specificity of the Gonozyme test for the detection of gonorrhoea in men with signs and symptoms of urethritis were high. Both indices were lower, however, in the other groups of patients studied. Several factors may explain these differences. It is reasonable to expect that the sensitivity of the immunoassay is related to the number of organisms in the collected specimen. On a scale of 1 to 4 the mean growth density of the cultures in group $\mathbf{A}$ was between grades 3 and 4 . In women with gonococcal cervicitis the growth density was lower and varied between grades 2 and 3 . The finding in four patients in whom gonococci were cultured but in whom the immunoassay results were negative or doubtful indicates the inherent risk if bacterial culture is replaced by the Gonozyme test. This risk should, however, be weighed against the nine (mainly female) patients who had positive results in the immunoassay but negative culture results. An explanation for this discrepancy may be that many patients in groups B and $\mathrm{D}$ regularly used a povidone-iodine douche. Although discordant results might be due to treatment with an antimicrobial agent before consultation none of the patients with discordant results between the Gonozyme test and bacterial culture had received these drugs before attendance at the clinic.

Microscopy of Gram-stained smears and the Gonozyme test can be considered as rapid tests for the detection of gonorrhoea. From a comparison of the results of both techniques the Gonozyme test was much more sensitive as a diagnostic test than microscopy in all groups except group $A$, in which these indices were high and equal. This is illustrated by the very low confidence limits of sensitivity of microscopy compared with those of immunoassay in patients in groups $B$ and D $(0 \cdot 1-29 \%$ and $0 \cdot 2-34 \%$ respectively).

The importance of the availability of a rapid test that is reasonably sensitive and specific hardly needs to be stressed. Takeguchi ${ }^{4}$ developed a test based on the detection of an enzyme produced in appreciable amounts only by $\boldsymbol{N}$ gonorrhoeae and Acinetobacter spp; in women the test had a sensitivity of $62-88 \%$ and a specificity of $48-71 \%$. These figures are lower than those of the Gonozyme test in women.

We thank Professor R van Strik of the Department of Biostatistics for his advice and Mrs A L Beukelman for her skilful assistance during the preparation of the manuscript.

\section{References}

1. Armstrong AS, Mathias JR, DeYoung MI, et al. Strain differentiation of Neisseria gonorrhoeae by reverse passive hemagglutination. Infect Immun 1979; 24:51-8.

2. Reyn A, Bentzon MW. Comparison of a selective and a nonselective medium in the diagnosis of gonorrhoea to ascertain the sensitivity of Neisseria gonorrhoeae to vancomycin. Br J Vener Dis 1972; 48: 363-8.

3. Taylor E, Phillips I. Assessment of a selective medium for the isolation of Neisseria gonorrhoeae. Br J Vener Dis 1979;55: 183-5.

4. Takeguchi MM, Weetall HH, Smith DK, et al. Enzymatic detection of Neisseria gonorrhoeae. Br J Vener Dis 1980;56: 304-7. 